\title{
iski \\ Pembelajaran Online sebagai Solusi Belajar di Masa Pandemi COVID-19
}

\author{
http://dx.doi.org/10.25008/wartaiski.v4i1.110
}

\author{
Sri Desti Purwatiningsih ${ }^{1}$, Dinar Soelistyowati ${ }^{2}$ \\ ${ }^{1}$ Program Studi Ilmu Komunikasi, Universitas Persada Indonesia Y.A.I \\ Jl. Pangeran Diponegoro No.74, Jakarta 10430 - Indonesia \\ ${ }^{2}$ Program Studi Ilmu Komunikasi, Universitas Bhayangkara \\ Jl. Raya Perjuangan, Bekasi Utara, Kota Bekasi 17121 - Indonesia \\ *e-mail korespondensi: psridesti@yahoo.com
}

Submitted: 09/03/2021, Revised: 29/05/2021, Accepted: 16/06/2021

Accredited by Kemristekdikti No. 30/E/KPT/2019

\begin{abstract}
Online media currently has a very important role in conveying information to the public. Especially during the COVID-19 pandemic which requires the implementation of social distancing, it is necessary to have a solution, especially in the world of education that minimizes the occurrence of face-to-face meetings, then learning media that utilize information and communication technology to support online learning, such as media (platforms). Google Classroom, Edmodo, Zenius, Zoom Meeting, Teams and others are widely used as learning media in the community. This study uses a Systematic Literature Review (SLR), which is a research method to identify, evaluate and interpret all relevant research results related to certain research questions, certain topics, or phenomena that are of concern to the author. The theory used is new media or online media as a product of technology-mediated communication with digital computers which consist of a combination of various elements. New media is media that uses the internet, technology-based online media, flexible character, interactive potential and can function privately and publicly. Learning through the use of online media is expected to provide convenience for educators and students because of the availability of various supporting facilities in new ways of learning provided by online media.
\end{abstract}

Keywords: Online media; learning media; COVID-19 pandemic; social distancing; systematic literature review

\begin{abstract}
Abstrak
Media daring (online) saat ini memiliki peran yang sangat penting dalam menyampaikan informasi kepada khalayak. Di masa pandemi COVID-19, penerapan social distancing memerlukan adanya solusi yang meminimalisir terjadinya pertemuan tatap muka. Media pembelajaran lalu memanfaatkan teknologi informasi dan komunikasi untuk menunjang pembelajaran secara online, seperti media platform Google Clasroom, Edmodo, Zenius, Zoom Meeting, Teams dan lain-lain. Penelitian ini menggunakan Systematic Literature Review (SLR) atau kajian studi kepustakaan, yaitu metode penelitian untuk melakukan identifikasi, evaluasi dan interpretasi terhadap semua hasil penelitian yang relevan terkait pertanyaan penelitian tertentu, topik tertentu, atau fenomena yang menjadi perhatian penulis. Teori yang digunakan new media atau media online sebagai produk dari komunikasi yang termediasi teknologi dengan komputer digital yang di dalamnya terdiri dari gabungan berbagai elemen. New media merupakan media yang menggunakan internet, berbasis teknologi, berkarakter fleksibel, berpotensi interaktif dan dapat berfungsi secara privat maupun secara publik. Hasil penelitian ini adalah Pembelajaran melalui pemanfaatan media online diharapkan memberikan kemudahan bagi dosen maupun mahasiswa dengan tersedianya berbagai fasilitas pendukung dalam cara belajar baru yang diberikan oleh media online.
\end{abstract}


Kata Kunci: Media online; media pembelajaran, pandemi COVID-19; jaga jarak, kajian studi kepustakaan

\section{PENDAHULUAN}

Pandemi Coronavirus Disease 2019 (COVID-19) sampai saat ini belum terbendung penyebarannya yang telah melanda lebih dari 215 negara di dunia sehingga menjadi tantangan tersendiri bagi dunia pendidikan untuk mencari solusi pembelajaran yang aman dari penyebaran virus tersebut. Penerapan physical distancing pada kehidupan new normal menjadi tantangan tersendiri bagi di dunia pendidikan yang biasanya mempertemukan pendidik dengan siswa dalam proses belajar mengajar secara tatap muka.

Di era new normal saat ini, dunia pendidikan dipaksa beradaptasi dengan cepat. Masa-masa transisi pembelajaran harus menggunakan metode online. Perguruan tinggi berusaha mencari solusi terkait bagaimana proses belajar mengajar di era new normal bisa tetap dilangsungkan, tanpa mengabaikan peran dosen sebagai pengajar dan mahasiswanya.

Melalui Kementerian Pendidikan dan Kebudayaan, Pemerintah telah melarang perguruan tinggi melaksanakan perkuliahan tatap muka (konvensional) dan memerintahkan untuk menyelenggarakan perkuliahan atau pembelajaran secara dalam jaringan (daring) atau online melalui Surat Edaran Kemendikbud Dikti No. 1 tahun 2020. Perguruan tinggi dituntut untuk dapat menyelenggarakan pembelajaran secara online (Firman, F., \& Rahayu, S., 2020).

Pembelajaran daring menggunakan memerlukan kerjasama antara dosen dan mahasiswa agar kegiatan kuliah bisa berjalan efektif. Keberhasilan pembelajaran ditentukan dari berbagai komponen yang saling berinteraksi, diantaranya dosen, mahasiswa, tujuan materi, metode, dan strategi pembelajaran (Rahman, A. M., Mutiani, M., \& Putra, M. A. H. 2019).

Pembelajaran secara online selama masa pandemi COVID-19 membuat sektor pendidikan mengalami perubahan besar. Para pendidik harus dapat beradaptasi dengan lingkungan yang mengharuskan mereka mengajar melalui media online. Menurut Moore, Dickson-Deane, \& Galyen (2011) pembelajaran daring merupakan pembelajaran yang menggunakan jaringan internet dengan aksesibilitas, konektivitas, fleksibilitas, dan kemampuan memunculkan interaksi pembelajaran.

Adaptasi dalam pengajaran melalui daring akibat Pandemi COVID-19 telah memberikan pengalaman baru bagi dosen dalam mengajar melalui berbagai platform seperti google classroom, google meet, zoom cloud, dan beragam aplikasi belajar lainnya secara online. Kementerian Pendidikan dan Kebudayaan juga menghadirkan program belajar melalui TVRI. Namun, media televisi merupakan media satu arah (one way communication) yang belum dapat menjawab kualitas capaian pembelajaran.

Ada sekitar 65 perguruan tinggi di Indonesia yang telah melaksanakan pembelajaran daring untuk mengantisipasi penyebaran COVID-19 (CNN Indonesia, 2020). Perkuliahan diselenggarakan dengan mencegah pertemuan fisik antara mahasiswa dengan dosen maupun mahasiswa dengan mahasiswa (Firman, F., \& Rahayu, S., 2020). Menurut Milman (2015) penggunaan teknologi digital memungkinkan mahasiswa dan dosen melaksanakan perkuliahan walaupun mereka di tempat yang berbeda.

Jamaluddin, D., Ratnasih, T., Gunawan, H., \& Paujiah, E. (2020) menyatakan pembelajaran daring memiliki kekuatan, tantangan dan hambatan tersendiri. Hambatan proses belajar secara online seperti fasilitas teknologi, jaringan internet, kesiapan dosen sebagai pendidik dan konten belajar yang baik harus segera dicarikan solusinya.

Pada tataran pelaksanaannya, pembelajaran daring memerlukan dukungan perangkat-perangkat mobile seperti smarphone atau telepon adroid, laptop, komputer, tablet, dan iphone yang dapat dipergunakan untuk mengakses informasi kapan saja dan dimana saja (Gikas \& Grant, 2013) saat perguruan tinggi melaksanakan work from home (WFH) secara daring (Darmalaksana, 2020). Pembelajaran secara daring telah menjadi tuntutan sejak beberapa tahun terakhir $(\mathrm{He}, \mathrm{Xu}, \&$ Kruck, 2014).

Pembelajaran secara daring diadakan bukan hanya karena pandemi COVID-19, tetapi juga memang sangat dibutuhkan di era revolusi industri 4.0 (Pangondian, R. A., Santosa, P. I., \& Nugroho, E., 2019). Penggunaan teknologi mobile mempunyai sumbangan besar dalam lembaga pendidikan, termasuk di dalamnya pencapaian tujuan pembelajaran jarak jauh (Korucu \& Alkan, 2011). Berbagai media online dapat digunakan untuk mendukung pelaksanaan pembelajaran secara daring, menggunakan layanan Google Classroom, Edmodo, dan Schoology (Enriquez, 2014; Sicat, 2015; Iftakhar, 2016) 
Dengan pemanfaatan tehnologi dalam pembelajaran, diharapkan pembelajaran akan lebih bisa diarahkan pada upaya perbaikan secara terus menerus, efektif, benar, dan objektif. Pemanfaatan teknologi ini akan memberikan keleluasaan bagi sekolah untuk melakukan berbagai macam modeling dalam menerapkan kegiatan pembelajaran. Menyikapi hal tersebut, seorang pendidik yang berperan sebagai aktor utama dalam pendidikan tidak boleh tutup mata. Pendidik saat ini harus lebih pintar dan cerdas dibandingkan para siswanya dalam menyikapi perkembangan teknologi yang semakin melesat. Untuk itu pendidik dapat dengan kreatif mengaplikasikan media online dalam pembelajaran digital.

Penelitian ini berfokus pada media pembelajaran online sebagai solusi belajar di masa pandemi COVID-19, bagi mahasiswa untuk meningkatkan minat belajar. Media pembelajaran online dengan berbagai variasi platform-nya menawarkan metode belajar yang menarik sesuai dengan fungsi yang ditawarkan masing-masing platform tersebut khususnya dalam situasi pandemi COVID-19 maka dapat dimanfaatkan dengan baik oleh dosen sebagai seorang pendidik untuk menciptakan suasana pembelajaran yang kondusif menarik dan kreatif.

Penelitian ini diharapkan dapat memberikan manfaat kepada masyarakat atas pentingnya media pembelajaran online sebagai solusi belajar baru di era Pandemi COVID-19. Media pembelajaran online bukan saja sebagai sarana informasi dan hiburan secara informal namun bisa menjadi sarana pembelajaran secara formal di bidang akademik.

\section{KERANGKA TEORI}

Teori yang digunakan dalam penelitian ini adalah teori media baru yaitu istilah yang dimaksudkan untuk mencakup kemunculan digital, komputer, atau jaringan teknologi informasi dan komunikasi di akhir abad ke-20. Untuk mengakses Internet, seseorang membutuhkan koneksi internet dan piranti keras seperti komputer, smartphone dan lain sebagainya. Internet yang dianggap sebagai gabungan dari beberapa bentuk media dan fasilitas email, website, newsgroup, e-commerce dan sebagainya (Lievrouw, 2006:221).

New media atau media online didefinisikan sebagai produk dari komunikasi yang termediasi teknologi yang terdapat bersama dengan komputer digital (Creeber dan Martin, 2009). Definisi lain media online adalah media yang di dalamnya terdiri dari gabungan berbagai elemen. Itu artinya terdapat konvergensi media di dalamnya: beberapa media dijadikan satu (Lievrouw, 2011). New media merupakan media yang menggunakan internet, media online berbasis teknologi, berkarakter fleksibel, berpotensi interaktif dan dapat berfungsi secara privat maupun secara publik (Mondry, 2008: 13).

Media baru secara digital adalah media yang kontennya berbentuk gabungan data, teks, suara, dan berbagai jenis gambar yang disimpan dalam format digital dan disebarluaskan melalui jaringan berbasis kabel optic broadband, satelit dan sistem gelombang mikro (Flew, 2008). Ciri-ciri utama internet sebagai media adalah: (1) Teknologi berbasis computer; (2) Karakteristiknya hibrida, tidak berdedikasi, fleksibel; (3) Potensi interaktif: (4) Fungsi publik dan privat; (5) Peraturan yang tidak ketat; (6) Kesaling-terhubungan; (7) Ada dimana-mana/tidak tergantung lokasi; (8) Dapat diakses individu sebagai komunikator; (9) Media komunikasi massa dan pribadi.

Secara sederhana media baru adalah media yang terbentuk dari interaksi antara manusia dengan komputer dan smartphone dan internet secara khusus. Termasuk di dalamnya adalah web, blog, online social network, online forum dan lain-lain yang menggunakan komputer sebagai medianya. New media adalah sebuah media yang memfasilitasi interaksi antara pengirim dan penerima (Danaher dan Davis, 2003).

Dalam hal ini teknologi komunikasi baru sangat terkait dengan tiga hal berikut, yaitu interactivity, de-massification, dan asynchronous. Interactivity dapat diartikan sebagai sebuah kemampuan untuk berbicara balik atau interaksi menggunakan sistem teknologi komunikasi baru. Metode yang lebih interaktif seperti ini membuat penggunanya dapat melakukan kegiatan komunikasi dengan lebih efektif dan juga optimal (Junaedi, 2011).

Media pembelajaran adalah segala bentuk alat komunikasi yang dapat digunakan untuk menyampaikan informasi dari sumber ke peserta didik secara terencana sehingga tercipta lingkungan belajar yang kondusif dimana penerimanya dapat melakukan proses belajar secara efisien dan efektif (Hamzah, Nina Lamatenggo, 2011).

Hamalik (2013) mengemukakan pemakaian media pembelajaran dalam proses pembelajaran dapat membangkitkan keinginan dan minat yang baru, membangkitkan motivasi dan rangsangan kegiatan belajar, dan bahkan membawa pengaruh-pengaruh psikologis terhadap mahasiswa. 
Media pembelajaran menurut Munadi (2013) adalah segala sesuatu yang dapat menyampaikan dan menyalurkan pesan dari sumber secara terencana sehingga tercipta lingkungan belajar yang kondusif di mana penerimanya dapat melakukan proses belajar secara efisien dan efektif. Pembelajaran adalah suatu usaha untuk membuat mahasiswa belajar atau suatu kegiatan untuk membelajarkan mahasiswa. Dengan kata lain, pembelajaran merupakan suatu upaya menciptakan kondisi agar terjadi kegiatan belajar.

Penggunaan smartphone dan laptop dalam pembelajaran daring dapat meningkatkan hasil belajar mahasiswa (Anggrawan, 2019). Pangondian, R. A., Santosa, P. I., \& Nugroho, E. (2019) menyatakan banyak kelebihan penggunaan teknologi informasi dan komunikasi dalam pelaksanaan pembelajaran daring diantaranya adalah tidak terikat ruang dan waktu. Beberapa penelitian telah membuktikan bahwa banyak pelajar yang menggunakan laptop dan smartphone dalam pembelajaran. Kemampuan laptop dan telepon pintar untuk mengakses internet memungkinkan mahasiswa untuk mengikuti kegiatan belajar mengajar yang dilaksanakan dalam bentuk konferensi video maupun yang dilaksanakan dalam kelas-kelas online menggunakan layanan aplikasi-aplikasi pembelajaran yang tersedia secara online (Kay \& Lauricella dalam Firman \& Sari, 2020).

Pembelajaran daring dengan menggunakan zoom cloud meeting memiliki kelebihan dapat berinteraksi langsung antara mahasiswa dan dosen serta bahan ajar tetapi memiliki kelemahan boros kuota dan kurang efektif apabila lebih dari 20 peserta didik (Naserly, M. K.,2020).

Pembelajaran daring juga memiliki kelebihan mampu menumbuhkan kemandirian belajar (self regulated learning). Penggunaan aplikasi online mampu meningkatkan kemandiri belajar (Oknisih, N, \& Suyoto, S., 2019). Kuo et al., (2014) menyatakan bahwa pembelajaran daring lebih bersifat berpusat pada mahasiswa yang menyebabkan mereka mampu memunculkan tanggung jawab dan otonomi dalam belajar (learning autuonomy). Belajar secara daring menuntut mahasiswa mempersiapkan sendiri pembelajarannya, mengevaluasi, mengatur dan secara simultan mempertahankan motiviasi dalam belajar (Sun, 2014; Aina, M., 2016). Sobron, A. N., \& Bayu, R. (2019) menyatakan bahwa pembelajaran daring dapat meningkatkan minat mahasiswa.

Media pembelajaran yang memanfaatkan Teknologi Informasi dan Komunikasi (TIK) untuk menunjang pembelajaran daring, seperti media (platform) Google Clasroom, Edmodo, Zenius, Zoom Meeting, Teams dan lain-lain. Media (platform) tersebut dijadikan sebagai sarana dosen untuk menjalankan proses pembelajaran pengganti tatap muka di kelas. Kecanggihan teknologi komunikasi tersebut menjadi media yang optimal dalam penyampaian materi/konsep, tugas berkala, ujian semester, bahkan dalam penyelesaian tugas akhir (Mushfi, 2019).

Daring memiliki tiga fungsi dalam kegiatan pembelajaran di dalam kelas (Siahaan, 2003) yakni: suplemen, komplemen, dan substitusi. Berfungsi sebagai suplemen (tambahan), apabila mahasiswa memiliki kebebasan memilih, apakah akan memanfaatkan materi daring atau tidak. Dalam hal ini, tidak ada kewajiban bagi mahasiswa untuk mengakses materi daring. Sekalipun sifatnya optional, mahasiswa yang memanfaatkannya tentu akan memiliki tambahan pengetahuan atau wawasan. Dikatakan berfungsi sebagai komplemen (pelengkap) apabila materi daring diprogramkan untuk melengkapi materi pembelajaran yang diterima siswa di dalam kelas.

Menurut Ghirardini (2011) pendekatan daring dapat menggabungkan berbagai jenis komponen daring, termasuk daring content, interaktif e-lesson, simulasi elektronik, job aids. Daring content (sumber sederhana belajar) adalah sumber daya non-interaktif seperti dokumen, Power Point presentasi, video atau file audio. Bahan-bahan ini non-interaktif dalam arti bahwa mahasiswa hanya dapat membaca atau menonton konten tanpa melakukan tindakan lain. Sumber daya ini dapat dengan cepat dikembangkan dan, ketika mereka cocok dengan yang ditetapkan tujuan belajar dan dirancang dalam cara yang terstruktur, sumber daya pembelajaran ini dapat menjadi berharga meskipun mereka tidak memberikan interaktivitas apapun.

Pembelajaran melalui daring karena lebih efektif dalam menghindari penyebaran virus corona dimana dalam perkembangannya, wabah penyakit COVID-19 yang pertama kali terjadi di Wuhan, China pada Desember 2019, hingga April 2020 telah menyebar hingga ke 210 negara, dengan karakterististik penyebarannya yang sangat cepat diantara manusia, ditambah dengan mobilitas manusia yang sangat tinggi dan lintas batas negara, menjadikan virus ini menjadi lebih berbahaya. 


\section{METODE PENELITIAN}

Penelitian ini menggunakan Systematic Literature Review (SLR) atau kajian studi kepustakaan, dengan melakukan identifikasi, evaluasi dan interpretasi terhadap semua hasil penelitian yang relevan terkait pertanyaan penelitian tertentu, topik tertentu, atau fenomena yang menjadi perhatian (Kitchenham, 2004). Systematic review merupakan studi sekunder (secondary study), yang sangat bermanfaat untuk melakukan sintesis dari berbagai hasil penelitian yang relevan, sehingga fakta yang disajikan kepada penentu kebijakan menjadi lebih komprehensif dan berimbang.

Sementara itu, pendekatan kualitatif dalam systematic review digunakan untuk mensintesis (merangkum) hasil-hasil penelitian yang bersifat deskriptif kualitatif. Metode mensintesis hasil-hasil penelitian kualitatif ini disebut dengan "meta sintesis". yaitu teknik melakukan integrasi data untuk mendapatkan teori maupun konsep baru atau tingkatan pemahaman yang lebih mendalam dan menyeluruh (Perry \& Hammond, 2002).

Dalam melakukan meta-sintesis pada penelitian ini digunakan pendekatan metaagregasi (metaaggregation). Pada metaagregasi, sintesis bertujuan untuk menjawab pertanyaan penelitian (review question) dengan cara merangkum berbagai hasil penelitian (summarizing) (Lewin, 2008). Pada metaagregasi topik penelitian dielaborasi menjadi tema-tema tertentu untuk menghasilkan kerangka analisis (conceptual framework). Kemudian, dalam tema-tema tertentu tersebut dilakukan pencarian artikel hasil penelitian yang relevan dan dibandingkan dan dirangkum antar yang satu dengan yang lainnya. Pada pendekatan meta-agregasi, hasil sintesis merupakan "agregat" dari berbagai hasil penelitian sesuai dengan tema yang relevan. (Francis \& Baldesari, 2006).

\section{HASIL PENELITIAN}

Media daring (online) sebagai media pembelajaran memiliki peranan yang penting dalam penyebaran informasi pengetahuan melalui berbagai platform yang dimilikinya seperti Facebook, Instagram, Youtube, Zoom, Google meet, Google Classroom, Whatsapp dan sederet platform lainnya yang memiliki kelebihan dalam setiap fungsinya sesuai dengan kondisi dan kebutuhan para pemakainya.

Berdasarkan hasil penelitian Sadikin dkk (2020) diketahui mahasiswa merasa lebih nyaman dalam mengemukakan gagasan dan pertanyaan dalam pembelajaran daring. Mengikuti pembelajaran dari rumah membuat mereka tidak merasakan tekanan psikologis dari teman sebaya yang biasa mereka alami ketika mengikuti pembelajaran tatap muka. Ketidakhadiran dosen secara langsung atau fisik juga menyebabkan mahasiswa merasa tidak canggung dalam mengutarakan gagasan.

Ketiadaan penghambat fisik serta batasan ruang dan waktu menyebabkan peserta didik lebih nyaman dalam berkomunikasi (Sun et all., 2008). Lebih lanjut, pembelajaran secara daring menghilangkan rasa canggung yang pada akhirnya membuat mahasiswa menjadi berani berekpresi dalam bertanya dan mengutarakan ide secara bebas. Pembelajaran daring juga memiliki kelebihan mampu menumbuhkan kemandirian belajar (self regulated learning).

Penggunaan aplikasi online mampu meningkatkan kemandirian belajar (Oknisih, N., \& Suyoto, S., 2019). Kuo et al., (2014) menyatakan bahwa pembelajaran daring lebih bersifat berpusat pada siswa yang menyebabkan mereka mampu memunculkan tanggung jawab dan otonomi dalam belajar (learning autuonomy). Belajar secara daring menuntut mahasiswa mempersiapkan sendiri pembelajarannya, mengevaluasi, mengatur dan secara simultan mempertahankan motiviasi dalam belajar (Sun, 2014; Aina, M.,2016).

Sobron, A. N., \& Bayu, R. (2019) menyatakan pembelajaran daring dapat meningkatkan minat peserta didik. Pembelajaran daring memiliki tantangan khusus. Lokasi mahasiswa dan dosen yang terpisah menyebabkan dosen tidak dapat mengawasi secara langsung kegiatan mahasiswa selama proses pembelajaran. Walaupun demikian proses pembelajaran harus terus berlangsung pada saat pandemi COVID-19 ini, dan kebijakan new normal serta kebijakan pemerintah terhadap pendidikan secara online atau daring tetap dilaksanakan agar generasi emas tidak ketinggalan pengetahuan dalam belajar dan tetap melakukan pembelajaran demi kemajuan generasi penerus sebagai tunas kemajuan bangsa di masa mendatang. Oleh karenanya tenaga pendidik harus dapat membekali mahasiswa mereka dengan pendidikan dan keterampilan yang kompeten dan kompleks artinya diharapkan harus mempunyai keterampilan berpikir kritis, konstruktif, runut dan juga berkarakter (Irwanto, 2020).

Hal ini sejalan dengan penelitian sebelumnya dari Istikomah, dkk (2017), Karim, dkk (2016) dan penelitian Novita, dkk (2015) yang menyatakan bahwa pembelajaran online dapat meningkatkan 
pemahaman peserta didik yang terdapat di berbagai jenjang sekolah dan berbagai materi. Diperkuat dengan hasil penelitian dari Sulisworo, dkk (2017), Ibrahim, dkk (2014), Aviva, dkk (2019), Wantara, dkk (2014) dan Syarif, dkk (2012) yang menyatakan bahwa pembelajaran online dapat meningkatkan motivasi belajar siswa dan akan meningkatkan pemahaman peserta didik.

Hanya saja tidak ada jaminan bahwa mahasiswa sunguh-sungguh dalam mendengarkan ulasan dari dosen. Szpunar, Moulton, \& Schacter, (2013) melaporkan dalam penelitiannya bahwa mahasiswa menghayal lebih sering pada perkuliahan daring dibandingkan ketika kuliah tatap muka. Selain itu berdasarkan hasil penelitian Argaheni (2020) diketahui pembelajaran daring memiliki beberapa dampak terhadap mahasiswa yaitu pembelajaran daring masih membingungkan mahasiswa; mahasiswa menjadi pasif, kurang kreatif dan produktif; penumpukan informasi/konsep pada mahasiswa kurang bermanfaat; mahasiswa mengalami stress; serta peningkatan kemampuan literasi bahasa mahasiswa.

Hal ini dapat menjadi evaluasi agar pembelajaran daring dapat diupayakan diterima dengan baik oleh mahasiswa tanpa mengurangi esensi pendidikan itu sendiri. Oleh karena itu disarankan pembelajaran daring sebaiknya diselenggarakan dalam waktu tidak lama mengingat mahasiswa sulit mempertahankan konsentrasinya apabila perkuliahan daring dilaksanakan lebih dari satu jam (Khan.,2012).

Beberapa hasil penelitian juga melaporkan bahwa tidak sedikit mahasiwa kesulitan dalam memahami materi perkuliahan yang diberikan secara daring. Bahan ajar biasa disampaikan dalam bentuk bacaan yang tidak mudah dipahami secara menyeluruh oleh mahasiswa (Sadikin, A., \& Hakim, N., 2019). Mereka berasumsi bahwa materi dan tugas tidak cukup karena perlu penjelasan secara langsung oleh dosen. Garrison \& Cleveland-Innes (2005) dan Swan (2002) melaporkan bahwa kelas yang dosennya sering masuk dan memberikan penjelasan memberikan pembelajaran lebih baik dibandingkan kelas yang dosennya jarang masuk kelas dan memberikan penjelasan.

Pembelajaran daring juga memiliki tantangan tersendiri. Salah satunya adalah ketersediaan jaringan internet. Beberapa mahasiswa mengaku kesulitan untuk mengikuti pembelajaran online karena tidak semua wilayah mendapatkan jaringan internet dengan akses lancar (Hasanah dkk, 2020). Hal tersebut membuat mereka kesulitan ketika akan mengumpulkan tugas. Selain tantangan mengenai layanan internet, tantangan lainnya adalah kendala biaya. Untuk mengikuti pembelajaran online, para siswa harus mengeluarkan biaya lebih untuk membeli kuota internet. Apalagi ketika pembelajaran dilakukan melalui video conference akan menghabiskan kuota internet sangat banyak. Berdasarkan informasi dari Din (dalam CNNIndonesia, 2020), konsumsi data untuk video conference menggunakan aplikasi zoom dengan kualitas video 720P selama satu jam menghabiskan data sebesar $540 \mathrm{MB}$.

Di masa pandemi COVID-19 saat ini dengan pembelajaran secara daring setidaknya dapat memutus mata rantai penyebaran COVID-19 di Perguruan Tinggi. Wabah ini menyerang sistem imun dan pernapasan manusia (Rothan \& Byrareddy, 2020) sehingga pencegahan nya dilakukan dengan menghindari interaksi langsung orang yang terinfeksi dengan orang-orang yang beresiko terpapar virus corona ini (Caley, Philp, \& McCracken, 2008). Mengatur jarak dan kontak fisik yang berpeluang menyebarkan virus disebut social distancing (Bell et al., 2006).

Mengaplikasikan media online sebagai sarana belajar baru juga dapat difungsikan sebagai sarana Pembelajaran Jarak Jauh (PJJ). Pembelajaran daring membuat siswa menjadi lebih mandiri, karena lebih menekankan pada student centered. Mereka lebih berani untuk mengemukakan pendapat dan ideidenya. Serta pemerintah juga telah menyediakan beberapa platform yang dapat digunakan mahasiswa untuk belajar (Handarini, 2020).

Sesuai dengan hasil penelitian Irwanto (2020), pembelajaran daring dapat membuat mahasiswa belajar mandiri dan motivasinya meningkat. Namun, ada kelemahan pembelajaran daring mahasiswa tidak terawasi dengan baik selama proses pembelajaran daring, lemah sinyal internet dan mahalnya biaya kuato menjadi tantangan tersendiri pembelajaran daring. Akan tetapi pembelajaran daring dapat menekan penyebaran COVID-19 di perguruan tinggi.

Pelaksanaan pembelajaran daring berjalan dengan lancar, namun dirasakan sebagian besar dosen dan mahasiswa kurang ideal dibandingkan pembelajaran tatap muka secara konvensional. Komunikasi terjalin kurang lancar menyebabkan materi menjadi sulit dipahami terutama mata kuliah praktikum. Hasil belajar mahasiswa dengan pembelajaran daring bervariasi, mulai dari kurang memuaskan, cukup hingga baik. kendala yang dihadapi mahasiswa dan dosen dalam pembelajaran daring adalah: ketersediaan kuota internet, jaringan yang terkadang tidak stabil, dan alat penunjang (Gawai dan Laptop). 
Pembelajaran daring dinilai efektif jika diterapkan pada masa pandemi COVID-19 karena berkaitan dengan protokol kesehatan. Dari hasil penelitian Irwanto (2020) juga diketahui diperlukannya model pembelajaran daring yang lebih variatif sebagai alternatif yang dapat digunakan dimasa mendatang agar pembelajaran tetap menarik sehingga tujuan dari pendidikan secara umum dapat tercapai. Meskipun pada saatnya nanti situasi Pandemi COVID-19 telah berakhir. Metode dapat digunakan khususnya untuk siswa yang sudah bekerja dan memiiki kendala bila harus belajar tatap muka di kampus.

\section{KESIMPULAN}

Pembelajaran secara daring merupakan salah satu solusi yang dapat diterapkan sebagai social distancing guna mencegah mata rantai penyebaran wabah COVID-19. Melalui pembelajaran secara daring, maka pembelajaran dapat dilakukan dengan jarak jauh atau pembelajaran yang dilakukan peserta didik di manapun dan kapanpun saat dibutuhkan, sehingga dapat menghindari kerumunan yang dianggap sebagai salah satu cara untuk menerapkan social distancing.

Pembelajaran secara daring membutuhkan sarana dan prasarana pendukung yang memadai, seperti laptop, komputer, smartphone dan jaringan internet yang stabil. Bagi siswa yang tidak memiliki laptop atau komputer, dapat menggunakan smartphone. Pembelajaran secara daring membuat siswa menjadi lebih mandiri, mereka lebih berani untuk mengemukakan pendapat dan ide-idenya karena merasa tidak ada tekanan dan merasa nyaman berada ditempat yang diinginkan.

\section{DAFTAR PUSTAKA}

Aina, M. (2016). Pengembangan Multimedia Interaktif Menggunakan Camtasia Studio 8 pada Pembelajaran Biologi Materi Kultur Jaringan untuk Siswa SMA Kelas XI MIA. Jurnal Biodik, 2(1). 20-26, https://online-journal.unja.ac.id

Anggrawan, A. (2019). Analisis Deskriptif Hasil Belajar Pembelajaran Tatap Muka dan Pembelajaran Online Menurut Gaya Belajar Mahasiswa. MATRIK: Jurnal Manajemen, Teknik Informatika dan Rekayasa Komputer, 18(2), 339-346. https://doi.org/10.30812/matrik.v18i2.411

Azhar, A, (2013). Media Pembelajaran, Jakarta: Raja Grafindo Persada.

Bell, D., Nicoll, A., Fukuda, K., Horby, P., Monto, A., Hayden, F.Van Tam, J. (2006). Nonpharmaceutical interventions for pandemic influenza, national and community measures. Emerging Infectious Diseases. https://doi.org/10.3201/eid1201.051371

Caley, P., Philp, D. J., \& McCracken, K. (2008). Quantifying social distancing arising from pandemic influenza. Journal of the Royal Society Interface. https://doi.org/10.1098/rsif.2007.1197

C, Briliannur Dwi., Amelia, A., Hasanah, U., Putra, A. M., Rahman, H. (2020). Analisis Keefektifan Pembelajaran Online di Masa Pandemi COVID-19. Jurnal Pendidikan Guru Sekolah Dasar. 2837

Cdc.gov, (2020),. Principles of Epidemiology in Public Health Practice, Third Edition An Introduction to Applied Epidemiology and Biostatistics, https://www.cdc.gov/csels/dsepd/ss1978/lesson1/section11.html pada 25 Maret pukul 17.17 WIB.

CNNIndonesia. (n.d.-a). 4 Aplikasi Video Conference yang Irit dan Boros Data. Retrieved from https://www.cnnindonesia.com/teknologi/20200330191529-185-488422/4-aplikasi- videoconference-yang-irit-dan-boros-data

Cooper dan Taylor dalam Mohammad Imam Farisi. (2010). Pengembangan Asesmen Diri Siswa (Student Self-Assessment) sebagai Model Penilaian dan Pengembangan Karakter. Artikel disampaikan pada Konferensi Ilmiah Nasional "Asesmen dan Pembangunan Karakter Bangsa" HEPI UNESA 2012.

Darmalaksana, W. (2020). WhatsApp Kuliah Mobile. Fakultas Ushuluddin UIN Sunan Gunung Djati Bandung.

Enriquez, M. A. S. (2014). Students' Perceptions on the Effectiveness of the Use of Edmodo as a Supplementary Tool for Learning. DLSU Research Congress. https://doi.org/10.1017/CBO9781107415324.004 .

Firman, F., \& Rahayu, S. (2020). Pembelajaran Online di Tengah Pandemi Covid19. Indonesian Journal of Educational Science (IJES), 2(2), 81-89.

Flew, T. (2008). New Media: An introduction. New York: Oxford University Pers.

Francis C. \& Baldesari (2006). Systematic Reviews of Qualitative Literature. Oxford: UK Cochrane Centre. 
Garrison, D. R., \& Cleveland-Innes, M. (2005). In Online Learning: Interaction is Not Enough. American Journal of Distance Education. https://doi.org/10.1207/s15389286ajde1903

Ghirardini, B. (2011). E-learning Methodologies. Germany: Federal Ministry of Food, Agriculture and Consumer Protection.

Gikas, J., \& Grant, M. M. (2013). Mobile computing devices in higher education: Student perspectives on learning with cellphones, smartphones \& social media. Internet and Higher Education. https://doi.org/10.1016/jijheduc.2013.06.002.

Gorbalenya AE, Baker SC, Baric RS, de Groot RJ, Drosten C, Gulyaeva AA, et al. (2020). The species Severe acute respiratory syndrome-related coronavirus: classifying 2019-nCoV and naming it SARS-CoV-2. Nat Microbiol.; published online March 2. http://doi.10.1038/s41564-020-0695-z.

Hamidah, Afreni., Sadikin Ali. (2020). Pembelajaran Daring di Tengah Wabah COVID-19. Jurnal Ilmiah Pendidikan Biologi. 6(02). 214-224

Hamzah, Nina Lamatenggo, (2011) Teknologi Komunikasi \& Informasi Pembelajaran, Jakarta: PT. Bumi Aksara.

Han Y, Yang H. (2020). The transmission and diagnosis of 2019 novel coronavirus infection disease (COVID-19): A Chinese perspective. J. Med Virol. https://doi.10.1002/ jmv.25749.

Handarini,O.I (2020), Pembelajaran Daring sebagai Upaya Study From Home (SFH) Selama Pandemi Covid 19, Jurnal Pendidikan Administrasi Perkantoran (JPAP) 8(3), 496 - 503.

Irwanto, (2020), Pelaksanaan Pembelajaran Online (Daring) di Program Studi Pendidikan Vokasional Teknk Elektro Untirta di Masa Pandemi COVID-19, Prosiding Seminar Nasional Pendidikan, $3(1), 28-44$.

Istiqomah, P, dkk. 2017. Pengaruh Penggunaan Media Video terhadap Peningkatan Pemahaman Konsep Suhu dan Kalor Pada Siswa Kelas X MAN 1 Palu. Jurnal Pendidikan Fisika Tadulako (JPFT), 5(3). http://jurnal.untad.ac.id/jurnal/index.php/EP FT/article/view/8868

Jamaluddin, D., Ratnasih, T., Gunawan, H., \& Paujiah, E. (2020). Pembelajaran daring masa pandemik COVID-19 pada calon guru: hambatan, solusi dan proyeksi. LP2M.

Junaedi, F. (ed). (2011). Komunikasi 2.0: Teoritisasi dan Implikasi. Yogyakarta: Aspikom.

Karyono, (2020), Penanganan dan Pencegahan Pandemi Wabah Virus Corona (COVID-19) Kabupaten Indramayu, Jurnal Kolaborasi Resolusi Konflik, 2(2). 164-174 https://doi.org/10.24198/jkrk.v2i2.29127.g13932.

Kay, R. H., \& Lauricella, S. (2011). Exploring the Benefits and Challenges of Using Laptop Computers in Higher Education Classrooms: A Formative Analysis. Canadian Journal of Learning and Technology /La Revue Canadienne de $l$ 'apprentissage et de La Technologie. https://doi.org/10.21432/t2s598.

Khan. S, (2012). The One World Schoolhouse. In Hachette Book Group. https://doi.org/10.1111/edth. 12072

Kitchenham, B. (2004). Procedures for Performing Systematic Reviews. Eversleigh: Keele University

Lusiana and M. Suryani, 2014 Metode SLR untuk Mengidentifikasi Isu-Isu dalam Software Engineering, Jurnal SATIN (Sains dan Teknol. Informasi), 3(1), 1-11.

McLuhan, Mashall. (1964) Understanding Media. New York: Mentor.

Milman, N. B. (2015). Distance Education. In International Encyclopedia of the Social \& Behavioral Sciences: Second Edition. https://doi.org/10.1016/B978-0-08- 097086-8.92001-4.

Musfhi, M, El Iq Bali. 2019. Implementasi Media Pembelajaran Berbasis Teknologi Informasi dan Komunikasi dalam Distance Learning. Jurnal TARBIYATUNA: Kajian Pendidikan Islam 3(1), 2940 http://ejournal.iaiibrahimy.ac.id/index.php/t arbiyatuna/article/view/198/

Naserly, M. K. (2020). Implementasi Zoom, Google Classroom, dan Whatsapp Group dalam Mendukung Pembelajaran Daring (Online) dada Mata Kuliah Bahasa Inggris Lanjut (Studi Kasus Pada 2 Kelas Semester 2, Jurusan Administrasi Bisnis, F).

Oknisih, N., \& Suyoto, S. (2019). Penggunaan Aplen (Aplikasi Online) Sebagai Upaya Kemandirian Belajar Siswa. In Seminar Nasional Pendidikan Dasar, 1(1)

Pangondian, R. A., Santosa, P. I., \& Nugroho, E. (2019). Faktor-Faktor yang Mempengaruhi Kesuksesan Pembelajaran Daring dalam Revolusi Industri 4.0. In Seminar Nasional Teknologi Komputer \& Sains (SAINTEKS) 1(1). 
Perry, A. \& Hammond, N. (2002). Systematic Review: The Experience of a PhD Student. Psychology Learning and Teaching, 2(1), 32-35.

Rahman, A. M., Mutiani, M., \& Putra, M. A. H. (2019). Pengaruh kompetensi pedagogik dosen terhadap motivasi belajar mahasiswa pendidikan IPS. Jurnal Darussalam: Jurnal Pendidikan, Komunikasi dan Pemikiran Hukum Islam, 10(2), 375-387.

Riedel S, Morse S, Mietzner T, Miller S. Jawetz, Melnick, \& Adelberg's (2019), Medical Microbiology. 28th ed. New York: McGrawHill Education/Medical;. 617-22.

Rothan HA, Byrareddy SN. (2020), The epidemiology and pathogenesis of coronavirus disease (COVID-19) outbreak. Journal of Autoimmunity. Academic Press;. 102433.

Sadikin Ali. dkk (2020), Pembelajaran Daring di Tengah Wabah COVID-19, BIODIK: Jurnal Ilmiah Pendidikan Biologi, 6(2), 214-224, https://online-journal.unja.ac.id/biodik.

Sampurno, M. Bayu Tejo., Kusmandyoko. Tri Cahyo., \& Islam. M. Ariffudin. (2020). Budaya Media Sosial, Edukasi Masyarakat, dan Pandemi COVID-19. Jurnal Sosial \& Budaya Syar'i. 7(6). 529542

Santika, I Wayan Eka. (2020). Pendidikan Karakter pada Pembelajaran Daring. Indonesian Values and Character Education Journal. 3(1). 2615-6938

Siahaan, S. (2003). E-learning (Pembelajaran Elektronik) Sebagai Salah Satu Alternatif Kegiatan Pembelajaran. Jurnal Pendidikan dan Kebudayaan. 42(9), 303-321

Sobron, A. N., \& Bayu, R. (2019). Persepsi Siswa Dalam Studi Pengaruh Daring Learning Terhadap Minat Belajar Ipa. Scaffolding: Jurnal Pendidikan Islam dan Multikulturalisme, 1(2), 30-38.

Sun, S. Y. H. (2014). Learner perspectives on fully online language learning. Distance Education. https://doi.org/10.1080/01587919.2014.891428

Szpunar, K. K., Moulton, S. T., \& Schacter, D. L. (2013). Mind wandering and education: From the classroom to online learning. Frontiers in Psychology. https://doi.org/10.3389/fpsyg.2013.00495

Sugiyono. (2012). Memahami Penelitian Kualitatif. Bandung: ALFABETA

Suharsimi, Arikunto. 2010. Prosedur Penelitian Suatu Pendekatan Praktik. Jakarta : Rineka Cipta.

Swan, K. (2002). Building Learning Communities in Online Courses: the importance of interaction. Education, Communication \& Information. https://doi.org/10.1080/1463631022000005016

Trianto,(2009), Mendesain Model Pembelajaran Inovatif - Progresif, Jakarta: Kencana

West, Richard; Turner, Lynn H. 2009 Teori Komunikasi. Jakarta: Salemba Pengantar Humanika. 